\title{
DIDELIO MEISTRIŠKUMO KREPŠINIO KOMANDŲ KAI KURIŲ ŽAIDIMO VEIKLOS RODIKLIŲ TYRIMAS
}

\author{
Stanislovas Stonkus, Mindaugas Balčiūnas, Tomas Stupuris, Mindaugas Tamušauskas \\ Lietuvos kūno kultūros akademija, Kaunas, Lietuva
}

Stanislovas Stonkus. Habilituotas socialinių mokslų daktaras. Lietuvos kūno kultūros akademijos Sportinių žaidimų katedros profesorius. Mokslinių tyrimų kryptys: kūno kultūros, sporto istorija ir terminologija; krepšinio komandų ir žaidèjų rengimo, žaidimo problemos.

\section{SANTRAUKA}

Metimu i krepš̀ technika ištirta pakankamai (Hayes, 1987; Hay, 1994 ir kt.), o rungtyniu rezultato priklausomybe nuо теtimu $i$ krepṣ̌ vietos ir puolimo struktūros reikalauja išsamesniu tyrimu.

Iškyla moksline problema: kokios metimu i krepṣ̌ vietos (krepšio ir nuotolio atžvilgiu) ir ataku trukmès bei pobūdžio sasajos su rungtyniu rezultatais. Treneriai per treniruotes ir rungtynes dažnai vadovaujasi intuicija, o ne objektyviais duomenimis, todèl tiriamoji problema yra aktuali. Svarbu nustatyti metimu i krepš̀̇ kiekybinius ir kokybinius rodiklius greitojo bei pozicinio puolimo metu; ištirti, kaip kiekybiniai ir kokybiniai metimu i krepš̨ rodikliai lemia rungtyniu rezultatus.

Per Eurolygos 2004 / 2005 metu sezono rungtynes buvo tiriama didelio meistriškumo krepšinio komandu $(n=20)$ žaidimo veikla registruojant rodiklius kompiuterine programa „Kregis “. Registruota: tiksliu metimu nuotolis, vieta; ataku trukme ir veiksmingumas.

Tyrimo tikslas - nustatyti ir żvertinti didelio meistriškumo krepšinio komandu kiekybinius ir kokybinius metimu $\dot{z}$ krepš̨̨ rodiklius, nuotolio, aikštès vietos ir puolimo struktūros požiüriu bei ju sasajas su rungtyniu rezultatais.

Tyrimo objektas - didelio meistriškumo krepšinio komandu metimu $\dot{z}$ krepš̨ veiksmingumas esant ivvairiai puolimo struktūrai.

Rungtynes laimejusios komandos vidutiniškai pelne po 86,5 taško: $57 \%$ metant iš artimo ir vidutinio, $24,2 \%$ iš tolimo nuotolio ir 18,8\% - baudos metimais. Rungtynes pralaimejjusios komandos - atitinkamai 80,7 taško ir 52,5, 30,7 ir 16,8\%. Rungtynes laimejusios komandos, mesdamos iš kairès aikštés pusès, surinko 36,3, iš dešinès - 31,9 ir iš aikštès vidurio 31,7\% visu tašku. Tirtos komandos per rungtynes surengè vidutiniškai po 79,4 atakas, kuriu efektyvumas 49,5\%. Veiksmingiausios atakos - trukusios $2-5 s-70 \%$.

Atliktas tyrimas rodo, kad pozicinis puolimas greitèja (10-15 s trukmès atakos) dèl gero iš anksto išmoktu deriniu taikymo arba individualiu puolančios komandos žaidèju savybiu, gebèjimu, pranašumu išnaudojimo.

Raktažodžiai: puolimo struktūra, pozicinis puolimas, žaidimo veikla, kompiuterinè programa „Kregis“.

\section{IVADAS}

$\mathrm{G}$ reta kitų sportinio rengimo tyrimo sričių (sportinio rengimo technologijos, sportinių rezultatų kaitos, atletų savybių ir kt.) svarbūs ir varžybinès veiklos požymių, jų kaitos tyrimai (Milanovič, 2000; Платонов, 2004).

Vieni iš svarbiausių krepšininkų technikos veiksmų yra kamuolio metimai į krepši. Tai sudètingi ataką užbaigiantys veiksmai, priklausantys nuo daugelio veiksnių: atskirų sąnarių judesių santykio (Millerr, Bartell, 1996), išmetimo kampo ir nuotolio (Miller, Bartlett, 1996), metimo i krepši vietos aikštėje (Stonkus ir Balčiūnas, 2001), puo- limo struktūros (Stonkus, 1985, 2003; Maksvytis, Stonkus, 2001; Gerani et al., 2004).

Metimu i krepši technika ištirta pakankamai (Hayes, 1987; Hay, 1994), o metimų i krepši veiksmingumo ir rungtyniu rezultato priklausomybè nuo metimu i krepši vietos ir puolimo struktūros reikalauja išsamesnių tyrimų (Sampaio et al., 2004).

Iškyla mokslinė problema: kokios metimu i krepši vietos (krepšio ir nuotolio atžvilgiu) ir atakų trukmès bei pobūdžio sąsajos su metimų $i$ krepši veiksmingumu ir rungtynių rezultatais. 
Tiriamoji problema aktuali, nes svarbu:

- Nustatyti metimu i krepši kiekybinius ir kokybinius rodiklius ivvairios trukmès greitojo ir pozicinio puolimo atakų metu.

- Ištirti, kaip metimų i krepši vieta lemia kiekybinius ir kokybinius rodiklius rungtynių metu.

Tyrimo objektas: didelio meistriškumo krepšinio komandų metimų $\mathfrak{i}$ krepši veiksmingumas esant ịvairiai puolimo struktūrai.

Tyrimo tikslas - nustatyti ir iqvertinti didelio meistriškumo krepšinio komandu kiekybinius ir kokybinius metimų i krepši rodiklius, nuotolio, aikštės vietos bei puolimo struktūros požiūriu ir jų sąsajas su rungtynių rezultatais.

\section{Uždaviniai:}

1. Nustatyti ir ịvertinti rungtynes laimëjusių ir pralaimejjusių komandų atakų trukmès rodiklius.

2. Nustatyti ir ivertinti rungtynes laimejjusių ir pralaimejjusių komandų vyraujančius metimų $i$ krepši rodiklius aikštės vietos požiūriu.

3. Nustatyti, koks metimu i krepši iš ivairių aikštès vietų ir rungtynių rezultatų ryšys.

\section{TYRIMO METODAI}

Taikyti šie tyrimo metodai:

1. Pedagoginis stebėjimas naudojant rungtynių ivykių registravimo kompiuterinę programa „Kregis".

2. Matematinė statistika.

Pedagoginis stebėjimas. Komandų žaidimo veiklos rodikliams registruoti buvo sukurta speciali kompiuterinè programa „Kregis“ (Balčiūnas, Karčiauskas, 2003), kurios svarbiausia paskirtis - registruoti metimu $\mathfrak{i}$ krepši vietą, kryptị ir nuotoli, atakų trukmę (1 pav.).

Matematinè statistika. Matematinès statistikos metodu apskaičiuoti rodikliai, leidžiantys apibendrinti ir lyginti atskiru tyrimu rezultatus: aritmetiniai vidurkiai $(\bar{x})$, vidurkiu standartiniai nuokrypiai (SD), vidurkių skirtumų reikšmingumo lygmuo $(\mathrm{p}<0,05)$ buvo apskaičiuojami naudojant MS Excel statistini paketą (funkcija TTEST).

\section{REZULTATAI}

Didelio meistriškumo vyrų krepšinio komandos 2004-2005 m. Eurolygos varžybose per vienerias rungtynes vidutiniškai surinko po 83,5 taškų: iš jų $55 \%$ (po 45,9 taško per rungtynes) pelnyta metant iš artimų ir vidutinių nuotolių ( 2 taškų zonos), $27 \%$ (po 22,4 taško) iš tolimų ( 3 taškų zonos) ir 18\% (po 15 taškų) metant baudos metimus (2 pav.).

Laimejjusios komandos vidutiniškai per rungtynes pelnè po 86,5 taško. Iš ju $57 \%$ (po 49,3 taško) metant iš artimu ir vidutinių nuotolių, iš tolimu $-24,2 \%$ (po 20,9 taško) ir $18,8 \%$ (po 16,3 taško) metant baudos metimus.

Pralaimejjusios komandos vidutiniškai per rungtynes pelnè po 80,7 taško. Iš jų: iš artimų ir vidutiniu nuotolių 52,5\% (po 42,36 taško), iš tolimu $-30,7 \%$ (po 24,8 taško), baudos metimais - 16,8\% visų tašku (po 13,5 taško).

Analizuodami tirtų didelio meistriškumo krepšinio komandų pelnytų taškų rodiklius pagal metimų vietą krepšio atžvilgiu nustatème, kad Eurolygos komandos vidutiniškai per rungtynes $35 \%$ (po 29,2 taško) visų tikslių metimų pelnè mesdamas i krepši iš kairès aikštès pusès, $34 \%$ (po 28,4 taško) - iš dešinès ir $31 \%$ (po 26 taško) - iš vidurio (3 pav.).

Rungtynes laimèjusios komandos daugiau taškų pelnè mesdamos iš kairès aikštès pusès $36,3 \%$ (po 31,1 taško) nei iš dešinès $-31,9 \%$ (po 28 taško), iš vidurio - 31,7\% (po 28 taško). Rungtynes pralaimèjusių komandu šie rodikliai

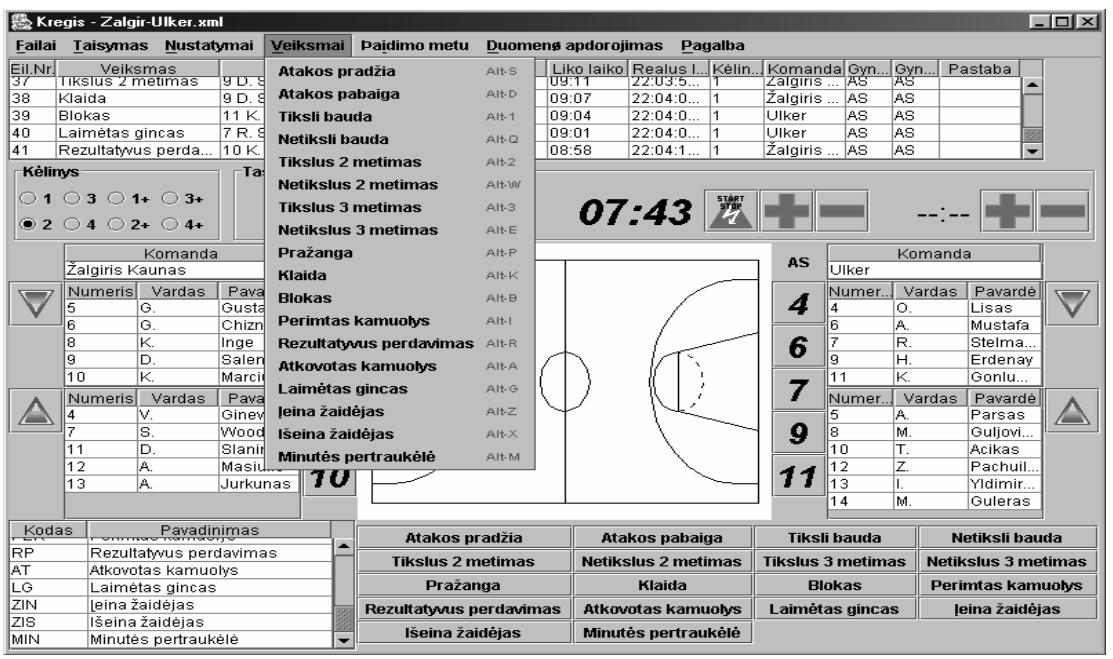

1 pav. Rungtynių ịvykių kompiuterinio registravimo protokolas 
2 pav. Didelio meistriškumo Eurolygos komandų 2004-2005 m. pelnomų taškų iš įvairių nuotolių skirstinys
3 pav. Didelio meistriškumo Eurolygos komandụ 2004-2005 m. tikslių metimų skirstinio rodikliai
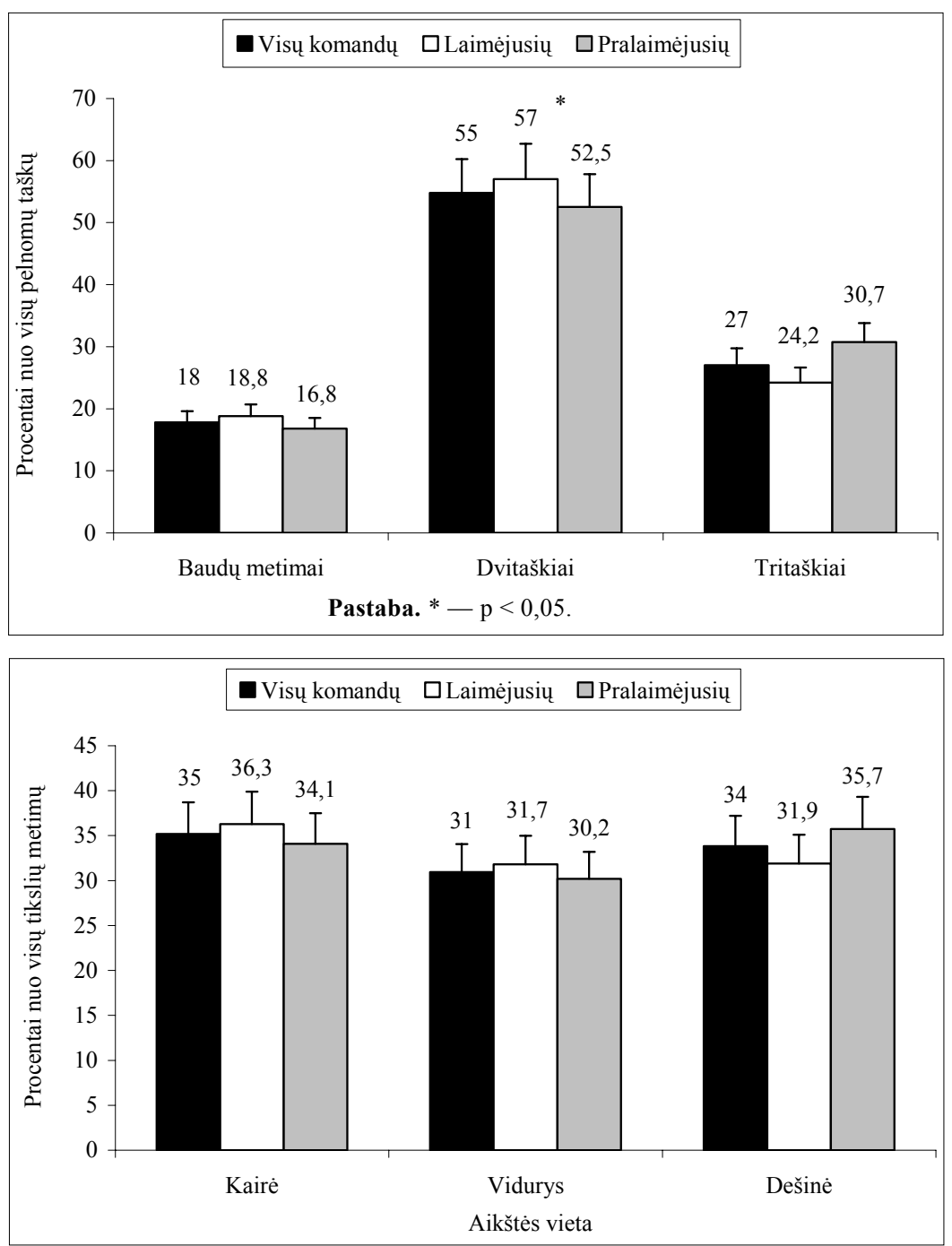

tokie: iš dešinès pusès - 35,7\% (po 27 taško), iš kairès - 34,1\% (po 24 taško), iš vidurio - 30,2\% (po 24 taško). Statistiškai reikšmingo skirtumo tarp jų nenustatyta $(\mathrm{p}>0,05)$.

Geriausios Eurolygos komandos per vienerias rungtynes tiksliai metė vidutiniškai po 45,4 karto: 23,3 dvitaškių, 7,4 tritaškių ir 14,7 baudos metimú. Daugiausia tikslių metimu - iš artimo nuotolio (atstumu iki 2 m nuo krepšio lanko). Tokie metimai sudare 55\% (25) visų metimu, tolimi metimai (per $6,25 \mathrm{~m})$ sudarè $27 \%(12,3)$ visų tikslių metimų, mažiausiai tikslių metimų iš vidutinio nuotolio: $3-4$ ir 5-6,25 m atstumu nuo krepšio lanko, ir tai sudare atitinkamai $7 \%(3,2)$ ir $11 \%(5)$ visų tikslių metimų (6 pav.).

Tyrimo duomenimis, geriausios Eurolygos vyru krepšinio komandos 2004-2005 m. vidutiniškai per rungtynes surenge po 79,4 atakas, veiksmingumas - 49,5\% (7 pav.).

Nagrinėdami Eurolygos vyrų krepšinio komandu atakų, trunkančių nuo 2 iki $5 \mathrm{~s}$, skaičių ir jų veiksmingumą nustatème, kad komandos vi- dutiniškai jų surengė po 19,3 (24,3\% visų atakų), veiksmingumas - 65\%. Laimèjusios komandos surengè po 20,1 greitojo puolimo atakos $(24,7 \%$ visų ataku), veiksmingumas $70 \%$, pralaimèjusios - po 18,4 (23,8\% visu ataku), veiksmingumas $60 \%,(8,9$ pav.; $p>0,05)$.

Atakų, kurios truko nuo 6 iki 9 s, vidutiniškai surengta $8,4(10,6 \%$ visų atakų) per rungtynes, jų veiksmingumas $-39,5 \%(p>0,05)$. Laimèjusios komandos surengè po $8,8(11,1 \%$ visų ata$\mathrm{ku})$, pralaimèjusios - po $8(10,1 \%$ visų atakų) $(\mathrm{p}>0,05)$.

$10-15$ s trukmès ataku komandos vidutiniškai per rungtynes surengdavo po 21 (26,4\% visu ataku), veiksmingumas $-39,5 \%(p>0,05)$. Laimèjusios komandos - po 21,1 (26,5\% visų ataku), pralaimèjusios - po 21 (26,4\% visų atakų) per rungtynes.

Atakuc, kurios trukdavo $16-20 \mathrm{~s}$, komandos vidutiniškai surengdavo $18,4(23,1 \%$ visu atakų) per rungtynes. Laimejjusios komandos - po 18,7 (23,5\% visų ataku), pralaimejusios - po 18 (22,6\% visu ataku) . 

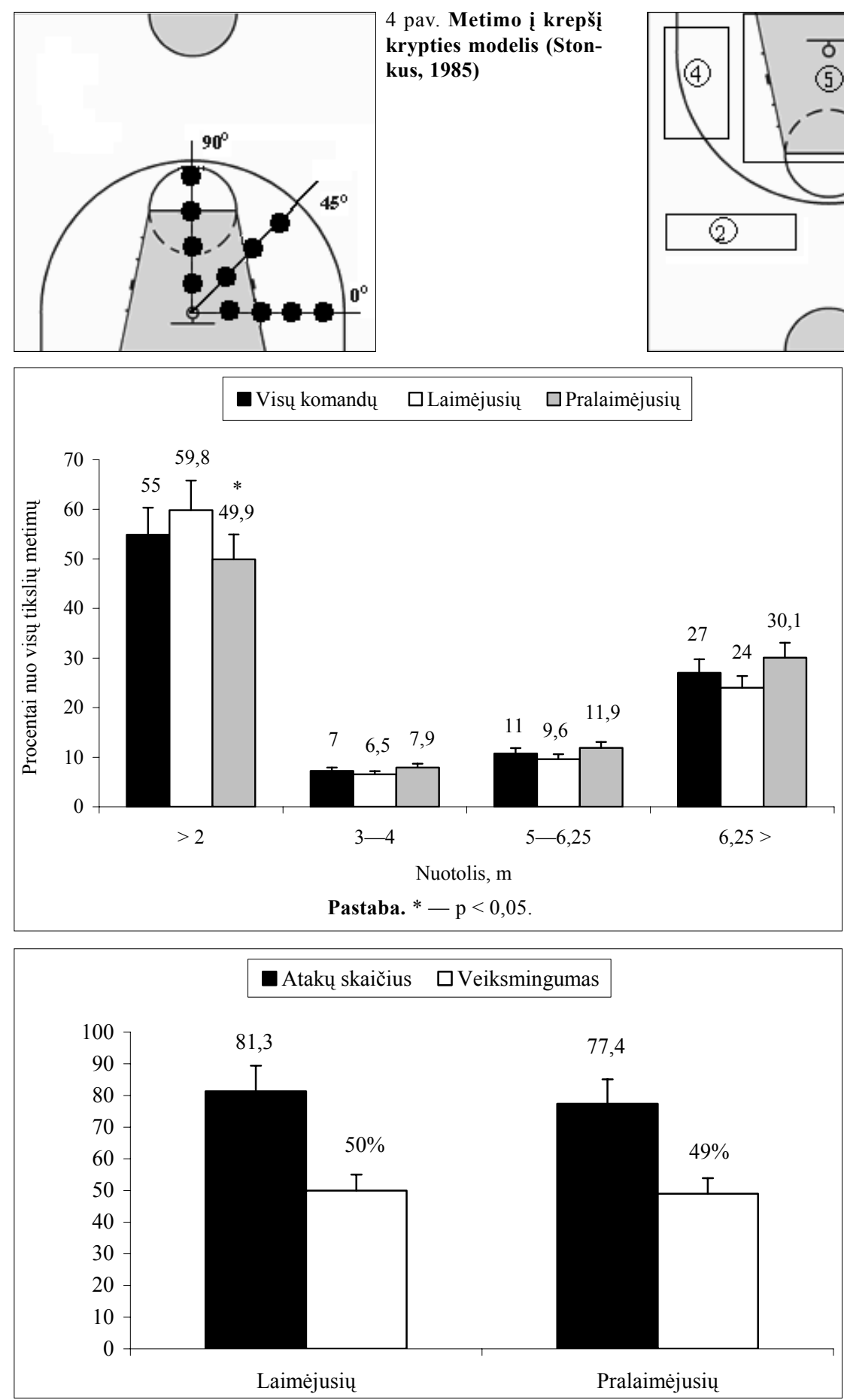

6 pav. Didelio meistriškumo Eurolygos komandų 2004-2005 m. tikslių metimų iš ivairių nuotolių per rungtynes skirstinys
$21-24 \mathrm{~s}$ trukmès ataku komandos per rungtynes vidutiniškai surengdavo po $12,3(15,5 \%$ visu ataku). Laimejjusios komandos - po 12,6 (15,8\% visų ataku), pralaimejjusios - po 12 (15,1\% visu ataku).

\section{REZULTATUQ APTARIMAS}

Lyginant laimejusių ir pralaimejjusių komandų pelnytus taškus iš įvairių nuotolių, ryškiai išsiskiria laimètojų pelnytų taškų iš artimų nuotolių skaičius. Tai patvirtina statistiškai patikimas
7 pav. Didelio meistriškumo Eurolygos komandų $2004-2005 \mathrm{~m}$. atakų skaičiaus ir jų veiksmingumo per rungtynes rodikliai $(\mathrm{p}<0,05)$ laimèjusių ir pralaimèjusių komandų pelnytų taškų iš artimo nuotolio rodiklių skirtumas (2 pav.).

Rungtynes pralaimejusios komandos metimais iš toli tašku pelnė daugiau (24,8 taško per rungtynes) nei laimejjusios (20,9 taško per rungtynes), tačiau statistiškai reikšmingo šio rodiklio skirtumo nenustatyta $(\mathrm{p}>0,05)$.

Tyrimo rezultatai iš dalies patvirtina autoriu (Deng et al., 2004), tyrusių NBA, olimpinèse žaidynèse ir pasaulio čempionatuose žaidusių komandų kiekybinius metimų $\mathfrak{i}$ krepši nuotolio 
8 pav. Didelio meistriškumo Eurolygos komandų 2004-2005 m. ịvairios trukmès atakų skaičius
9 pav. Didelio meistriškumo Eurolygos komandu $2004-2005 \mathrm{~m}$. ivvairios trukmès atakų veiksmingumo rodikliai
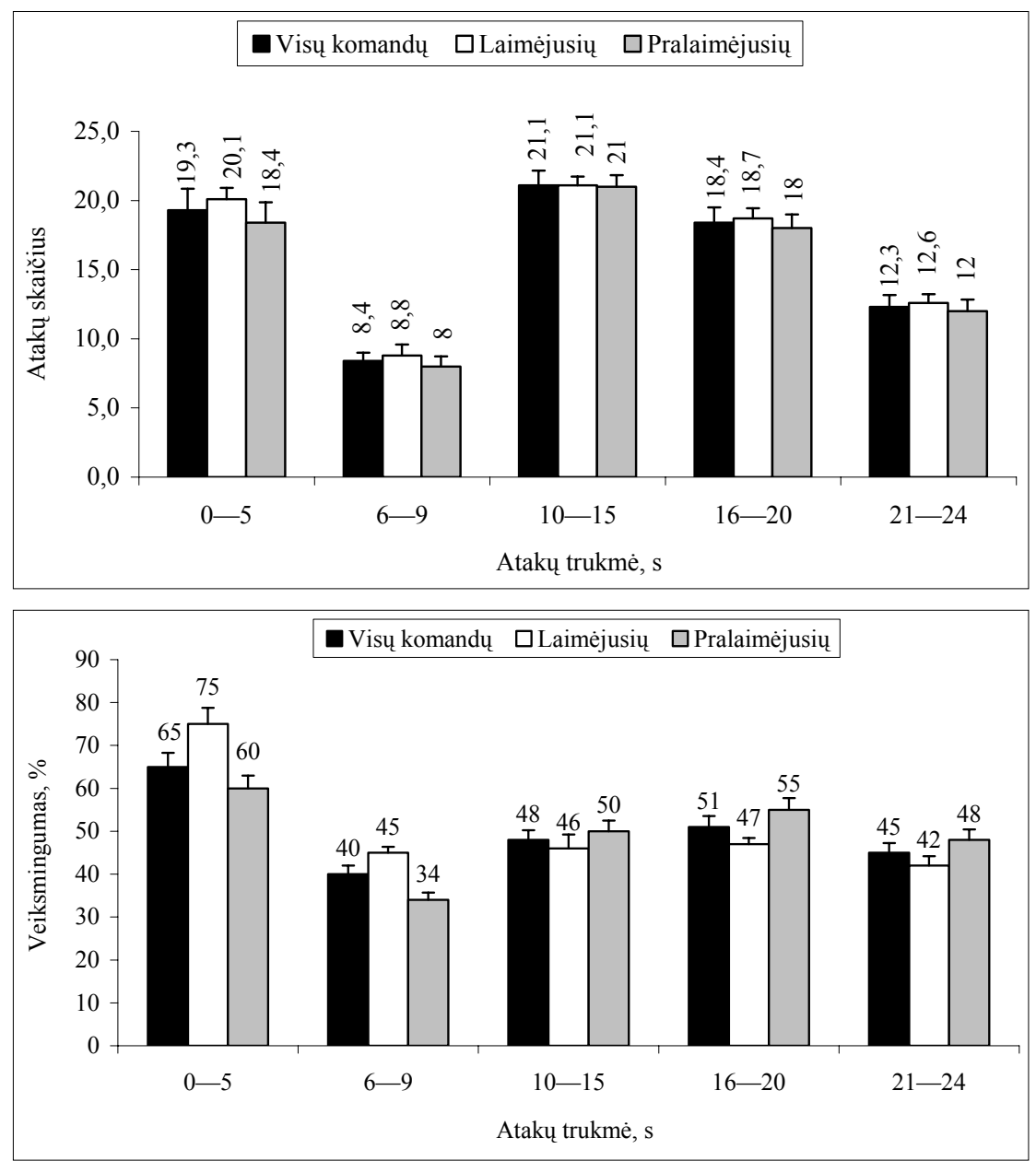

atžvilgiu rodiklius ir išvadas - komandos, neturinčios veiksmingai puolančiu priekinès linijos žaidejjų (vidurio puolejjų), daugiau meta ir pelno taškų iš tolimų nuotolių.

Anot kai kurių autorių (Deng et al., 2004), NBA varžybose tolimi metimai sudaro $18 \%$ visu metimų, jų veiksmingumas - 36,9\%. Mūsų tirtų geriausiu Eurolygos komandu - 28\% visu metimu, veiksmingumas $-36,9 \%$. Tolimų metimų skaičius daugiausia priklauso nuo komandos galimybių ir pasirinktos žaidimo taktikos (Deng et al., 2004), kurią visu pirma lemia komandos vidurio puolèjų meistriškumas, jų panaudojimas komandai puolant.

Geresni rungtynes laimejjusių komandų kiekybiniai tiksliu metimų iš kairès aikštès pusès rodikliai yra dèl varžovų taikomos gynybos taktikos (kai aktyvesné gynyba yra dešinejje aikštès pusejje). Kaip teigia S. Stonkus (1985), metimų i krepši tikslumas priklauso nuo nuotolio, iš kurio metama (68-72\%), krypties (17-28\%) ir metimo būdo (3-13\%). Krypties atžvilgiu tiksliausi metimai iš taškų, sudarančių $90^{\circ}$ kampą su krepšio skydo plokštuma (4 pav.), ne tokie tikslūs $-45^{\circ}$ ir netiksliausi $-0^{\circ}$ kampa (Stonkus, 1985). Taip pat metimu vieta priklauso nuo aikštès ploto, kuriame veikia žaidèjas. Tinkamiausi žaidèjų veikimo plotai parodyti (5 pav.).

Tirtos komandos iš ploto, esančio prieš krepši, metè mažiausiai (31\%), nes čia yra didžiausia galimybè pataikyti. Komandos dažniausiai naudoja gynybos taktiką, neleidžiančią atlikti tokių metimų.

Lyginant rungtynes laimèjusių ir pralaimejjusiu komandų tikslių metimu iš îvairių nuotolių rodiklius nustatyta, kad vieni iš esminių komandos žaidimo rodiklių, lemiančių komandos pergalę rungtynèse, yra tikslūs metimai iš arti. Laimejjusi komanda per Eurolygos rungtynes tiksliai iš artimo nuotolio atakavo krepši statistiškai reikšmingai dažniau (59,8\% visų tikslių metimų) nei pralaimejjusi $(49,9 \%$ visų tikslių metimu) $(\mathrm{p}<0,05)$. Metimai ị krepši iš toli (per 6,25 m) rodè atvirkščią, nors ir statistiškai nereikšmingą $(\mathrm{p}>0,05)$, tendenciją: rungtynes pralaimejusios komandos tiksliai atakavo krepši iš toli dažniau $(30,1 \%$ visų tikslių metimu), nei rungtynes laimejjusios komandos (24\% visų tikslių metimų).

Tiek rungtynes laimèjusios, tiek pralaimèjusios komandos mažiausiai pataikè iš vidutinio nuotolio (3-4 ir 5-6,25 m) - atitinkamai: lai- 


\begin{tabular}{|l|l|l|l|l|}
\hline \multirow{2}{*}{ Atakų trukmé, s } & \multicolumn{2}{|l|}{$2000-2001 \mathrm{~m}$. sezonas } & \multicolumn{2}{l|}{ 2004-2005 m. sezonas } \\
\cline { 2 - 5 } & Atakų skaičius & Veiksmingumas, \% & Atakų skaičius & Veiksmingumas, \% \\
\hline $2-5$ & 14,3 & 72 & $19,3( \pm 1,5)$ & $65( \pm 3,2)$ \\
\hline $6-9$ & 23,4 & 49 & $8,4( \pm 0,6)$ & $39,5( \pm 2,6)$ \\
\hline $10-15$ & 30,5 & 54 & $21( \pm 1,01)$ & $48( \pm 3,24)$ \\
\hline $16-20$ & 23,4 & 52 & $18,4( \pm 1,1)$ & $51( \pm 4,6)$ \\
\hline $21-24$ & 8,5 & 46 & $12,3( \pm 0,8)$ & $45( \pm 3,3)$ \\
\hline
\end{tabular}

mejjusios $-6,5$ ir $9,6 \%$, pralaimejusios $-7,9$ ir $11,9 \%$ visų tikslių metimų $(\mathrm{p}>0,05)$.

Remiantis literatūroje pateiktais duomenimis, $2001 \mathrm{~m}$. Eurolygos ir Suprolygos varžybose vidutiniškai per rungtynes vyrų krepšinio komandos surengdavo po 91 ataką, jų veiksmingumas $52,7 \%$ (Stonkus, 2003).

Lyginant rungtynes laimejjusių ir pralaimejjusių komandų surengtų atakų skaičių paaiškèjo, kad komanda nugalètoja vidutiniškai per rungtynes surengdavo 81,3 atakos, veiksmingumas $-50 \%$, pralaimejusi komanda - 77,4 atakos, veiksmingumas - $49 \%$.

Nagrinejjant Eurolygos vyrų krepšinio komandų greitojo puolimo atakų skaičių ir jų veiksmingumą nustatyta, kad per rungtynes ataku, trukusiu 2 - 5 s, komandos vidutiniškai surengdavo po 19,3 (24,3\% visų atakų), veiksmingumas - 65\%. Laiméjusios komandos - po 20,1 greitojo puolimo atakos $(24,7 \%$ visu ataku), veiksmingumas $70 \%$, pralaimejjusios - po $18,4(23,8 \%$ visu atakų), veiksmingumas $-60 \%(8,9$ pav.; $p>0,05)$.

Analizuojant pozicinio puolimo rodiklius nustatyta, kad daugiausia surengta ataku, kurios trukdavo 10 - $15 \mathrm{~s}$, jų vidutiniškai komandos surengdavo po 21 per rungtynes (26,4\% visų ataku), veiksmingumas - 48\%. Mažiausiai surengta $6-9 \mathrm{~s}$ trukmès ataku $-8,4$ atakos per rungtynes $(10,6 \%$ visu ata$\mathrm{ku})$, veiksmingumas $-39,5 \%(\mathrm{p}>0,05)$.

Pozicinio puolimo atakas veiksmingiau rengè rungtynes pralaimejjusios komandos, jų atakų veiksmingumas - 46,8\% (laimèjusių — 45\%), tačiau rungtynes laimejjusios komandos pozicinio puolimo ataku surengdavo daugiau - po $62,2(76,5 \%$ visu ataku) atakos, tuo tarpu pralaimejjusios po 58 $(74,9 \%$ visu ataku) atakas $(\mathrm{p}>0,05)$.

Per 2004-2005 m. sezoną Eurolygos komandu greitojo ir pozicinio puolimo kiekybiniai ir kokybiniai rodikliai buvo prastesni už $2000-2001 \mathrm{~m}$. sezono (žr. lent.) rodiklius (Stonkus, 2003).

Kiekybiniai (8 pav.) komandu puolimo struktūros rodikliai (ataku skaičius per rungtynes) artimi idealiam puolimo struktūros modeliui, kuri pateike K. Maksvytis ir S. Stonkus (2001), tačiau kokybiniai buvo daug blogesni (9 pav.).
Vadinasi, idealus modelis buvo sudaromas ką tik pasikeitus žaidimo taisyklèms (2001 m.), kai komandos žaidè iš dalies pasikeitusiomis sąlygomis. Atlikto tyrimo rezultatai rodo, kad praejjus ketveriems metams komandos geriau prisitaikè prie trumpesnès atakų trukmès, surengè daugiau greitu atakų, mažiau krepši atakavo skubotai $(6-9 \mathrm{~s})$.

\section{IŠVADOS}

1. Rezultatai patvirtino anksčiau skelbtus panašių tyrimų rezultatus. Veiksmingiausios atakos puolant trunka iki $5 \mathrm{~s}$, todèl treneriai turètu atkreipti ypatingą dèmesi i greitojo puolimo organizavimą. Tiek Eurolygos rungtynes laimejjusių, tiek pralaimejjusių komandų atakos dažniausiai trukdavo 2-5 s (atitinkamai: 20,1 ir 18,4 atakos vidutiniškai per rungtynes) ir 10-15 s (atitinkamai: 20,1 ir 20 ataku per rungtynes), tačiau skyrèsi jų veiksmingumas: $2-5 \mathrm{~s}$ ataku veiksmingumas puolant rungtynes laimèjusioms komandoms siekè $70 \%$, pralaimejjusioms - 60\%, 10-15 s (atitinkamai: 46 ir $50 \%)$.

2. Tyrimo statistika patvirtino laimejusių komandu pranašumą atakuojant krepšş iš arti: per 20042005 m. Eurolygos varžybas laimejjusi komanda tiksliausiai metè iš arti (iki $2 \mathrm{~m}$ ) $-59,8 \%$ visų tikslių metimų. Tai naujas ir literatūroje mažai akcentuotas komandos žaidimo sèkmès veiksnys. Tuo tarpu mažiausiai rungtynių laimejjusios komandos atakavo iš $2-4 \mathrm{~m}$ atstumo $-6,5 \%$. Rungtynes laimèjusi komanda tiksliau krepši atakavo iš kairès aikštès pusès - 36,3\% tiksliu metimų, rungtynes pralaimejjusi — iš dešinès $35,7 \%$ visų tikslių metimų.

3. Rungtynių rezultatus nuotolio požiūriu daugiausia lèmé metimai į krepši atstumu iki $2 \mathrm{~m}$, jie sudarè $55 \%$ visų tikslių metimų (po 45,9 taško per rungtynes). Metimų i krepši rezultatas krypties požiūriu labai panašus. Skirtumas tarp veiksmingų metimų iš įvairių aikštès pusių svyruoja nuo 1 iki $4 \%$. Atitinkamai iš kairès - $35 \%$, iš dešinès $-34 \%$, iš vidurio $-31 \%$. 


\title{
LITERATŪRA
}

Balčiūnas, M., Karčiauskas, E. (2003). Kompiuterinė krepšinio įvykių registravimo programa. Lietuvos mokslas ir pramone, saus. 28. Kaunas: KTU.

Deng, F., Guo, D., Zhang, Z. (2004). 3 point shot performance analysis. $7^{\text {th }}$ Annual Congress of the European College of Sport Science, Zalsburg, 24-28 July.

Gerani, H., Mexas, K., Garefis, A., Tsitskaris, G. (2004). The Effectiveness of Fast Breaks in High-Level Basketball. Athens: Pre-Olympic Congress.

Hayes, D. (1987). Body segment contribution to free throws shooting in Basketball. Biomechanics in Sports. Proceedings of the Fifth International Symposium of Biomechanics in Sports (pp. 205-211). Athens: Hellenic Sports Research Institute.

Hay, J. G. (1994). The Biomechanics of Sports Techniques. USA: Practice-Hall. P. 211-234.

Maksvytis, K., Stonkus, S. (2001). Didelio meistriškumo vyrų krepšinio komandų puolimo struktūra. Sporto mokslas, 1 (23), 46-50.
Milanovič, D. (2000). Structure and characteristics of scientific research in the domain of sport. $5^{\text {th }}$ Annual Congress of the European College of Sport Science, Jyväskylä, Finland.

Millerr, S. A., Bartlett, R. M. (1996). The relationship between basketball shooting kinematics, distance and playing position. Journal of Sports Sciences, 14, 243-253.

Sampaio, J, Ferreira, A., Ibanez, S. (2004). Field-goal efficiency in winning and losing basketball games; investigation of court location, player position, prior action to shooting and defensive opposition. $9^{\text {th }}$ Annual Congress of the European College of Sport Science, Clermont - Ferrand, France, 3-6, July.

Stonkus, S. (2003). Krep̌̌inis. Kaunas: LKKA.

Stonkus, S. (1985). Krepšinis. Vilnius: Mokslas.

Платонов, В. Н. (2004). Система подготовки спортсменов в олимпийском спорте. Киев: Олимпийская литература.

\section{ANALYSIS OF CHOSEN OFFENSIVE INDICES OF ELITE BASKETBALL TEAM PERFORMANCE}

\author{
Stanislovas Stonkus, Mindaugas Balčiūnas, Tomas Stupuris, Mindaugas Tamušauskas \\ Lithuanian Academy of Physical Education, Kaunas, Lithuania
}

\begin{abstract}
The techniques for basketball throwing have been researched to a sufficient extent (Hayes, 1987; Hay et al., 1994), meanwhile the competition result dependence on throwing place and offence structure requires more profound investigation.

Consequently, the following scientific problem has been formulated: what influence on competition results has the ball throwing place (with regard to the basket and distance), attack duration and its character have. During training sessions and competitions, coaches frequently make decisions basing them on the intuition, not on objective data; thus the problem being surveyed has come to be an actual one, as it is important to establish the quantitative and qualitative parameters during high speed offensive attack or free flowing offence; it is important as well to investigate the influence of quantitative and qualitative factors on a competition result.

The play performance of the elite basketball teams $(n=20)$ has been investigated during Euro League competitions in the season of 2004/2005 applying the computer program "Kregis" to register the parameters. The following parameters have been registered: dunk shot distance and place; attack duration and efficiency.

The objective of the survey was to establish and assess the elite basketball team quantitative and qualitative parameters concerning ball throwing into the basket with regard to the distance, the place on the court and attack structure, and their influence on the competition result as well.

The object of the survey was the efficiency of ball throwing into the basket of elite basketball teams under conditions of different attack structures.

The survey conducted has shown the increase in speed of free flowing offence (duration 10-15 s) caused by the proper usage of the game match ups that have been mastered in advance, or by taking advantage of individual qualities, abilities and excellence of the offensive team players.
\end{abstract}

Keywords: attack structure, free flowing offence, play performance, computer program "Kregis".

Gauta 2007 m. vasario 13 d.

Received on February 13, 2007

Priimta 2007 m. balandžio 24 d.

Accepted on April 24, 2007
Stanislovas Stonkus

Lietuvos kūno kultūros akademija

(Lithuanian Academy of Physical Education)

Sporto g. 6, LT-44221 Kaunas

Lietuva (Lithuania)

Tel +370 37302636 